\title{
Mauna Loa-History, Hazards, and Risk of Living With the World's Largest Volcano
}

auna Loa on the Island of
Hawai'i is the world's largest
volcano. People residing on its flanks
face many hazards that come with
living on or near an active volcano,
including lava flows, explosive erup-
tions, volcanic smog, damaging
earthquakes, and local tsunami (giant
seawaves). The County of Hawai' $i$
(Island of Hawai'i) is the fastest grow-
ing County in the State of Hawaii. Its
expanding population and increas-
ing development mean that risk from
volcano hazards will continue to
grow. U.S. Geological Survey (USGS)
scientists at the Hawaiian Volcano
Observatory (HVO) closely monitor
and study Mauna Loa Volcano to
enable timely warning of hazardous
activity and help protect lives and
property.

Mauna Loa, the world's largest volcano, encompasses more than half the Island of Hawai ' $i$ and rises to 4,169 meters (13,679 feet) above the Pacific Ocean. A very active volcano, it has produced large, voluminous flows of basalt (very fluid, dark lava) that have reached the ocean eight times since 1868. It last erupted in 1984, when a lava flow came within $7.2 \mathrm{~km}$ (4.5 miles) of Hilo, the largest population center on the island. With such a propensity to produce large flows, Mauna Loa is considered a "high priority" for monitoring by the U.S. Geological Survey (USGS).

In Hawai' $i$, eruptions of basalt are, in general, placid outpourings of fluid lava flows, building the gentle slopes characteristic of "shield" volcanoes. The greatest direct hazards associated with shield volcanoes are the lava flows and emissions of volcanic gases. Although these seldom cause deaths, lava flows typically do extensive damage by covering, burning, and crushing everything in their path. Basalt flows can travel more than $50 \mathrm{~km}$ from their vent, making most communities on the Island of Hawai 'i susceptible to lava-flow inundation. And gas emissions can be carried by the wind and reach other islands in the State, producing human health concerns and damaging crops and livestock.

Mauna Loa has a summit caldera (a large oval volcanic depression) and two rift zones

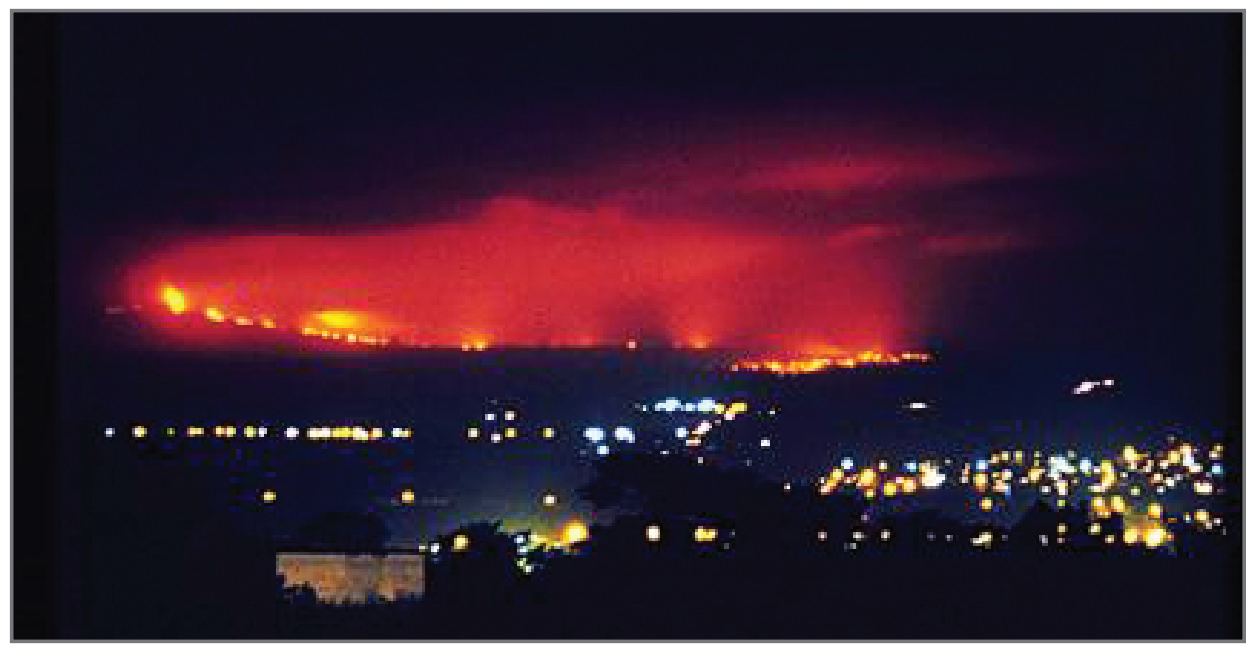

Mauna Loa, the world's largest volcano, has erupted many times, producing large and long-traveled lava flows, and it will erupt again and pose a significant risk to inhabitants of the Island of Hawai'i. During its most recent eruption in 1984, a lava flow approached the city of Hilo, as seen in this nighttime photograph (photo by David Little).

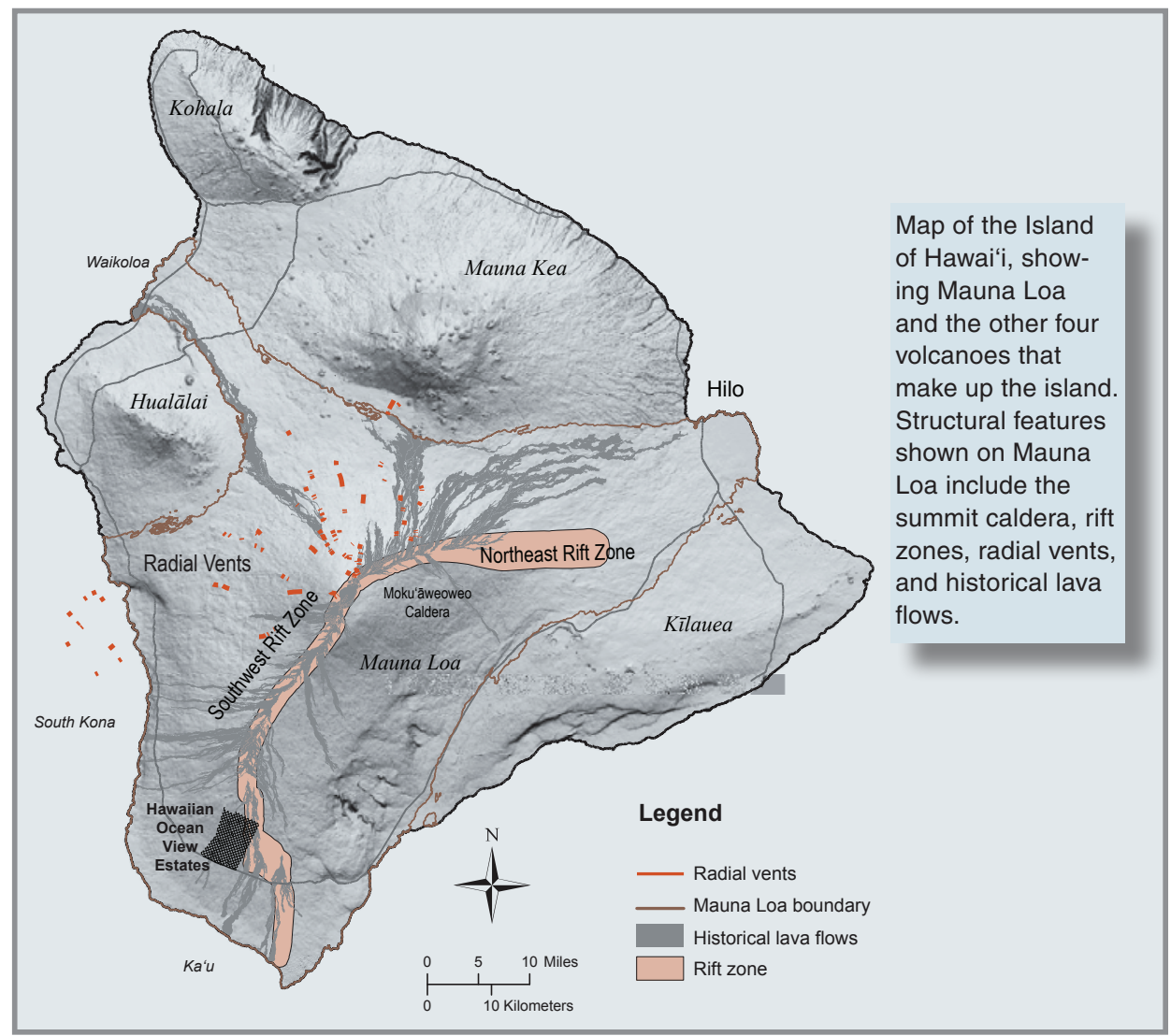




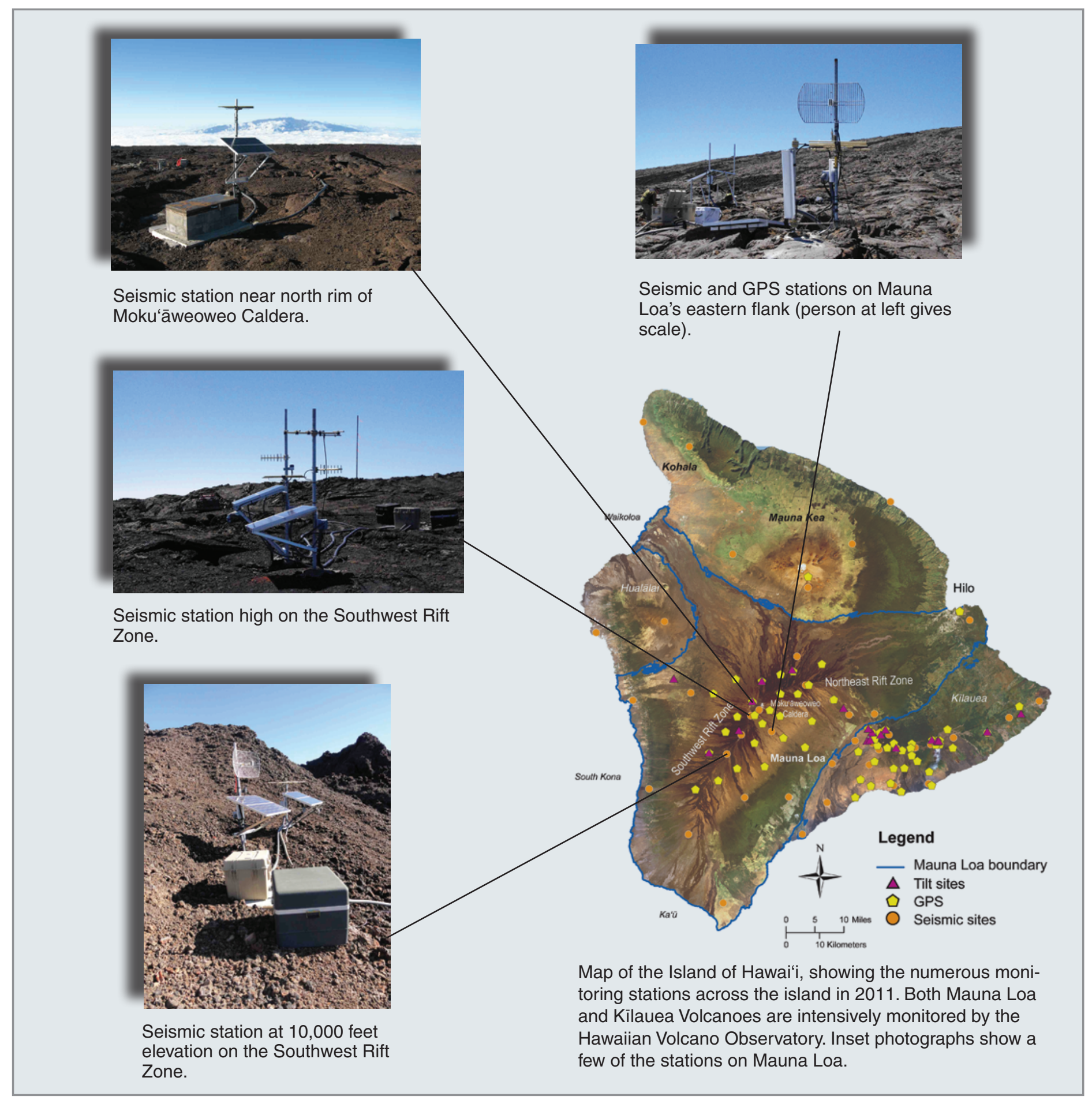

extending northeast and southwest from the caldera. Most of Mauna Loa's eruptions begin with lava fountains from a series of fissure vents in the summit region and then often migrate to vents down either rift zone.

Mauna Loa eruptions produce lava at a much higher rate than those of any other Hawaiian volcano, even the highly active neighboring Killauea volcano, resulting in fast-moving and long-travelled lava flows. Such high eruption rates require quick responses in order to protect life and property.

\section{Eruptive History of Mauna Loa}

Mauna Loa erupts frequently_over the past 3,000 years it has erupted lava flows, on average, every 6 years. Since 1843, Mauna Loa has erupted 33 times, averaging one eruption every 5 years. All historically recorded Mauna Loa eruptions started in the summit area, and approximately half have stayed in the summit. Seventeen continued from vents in the volcano's rift zones, producing lava flows that covered broad areas on the lower slopes of the volcano.
Seven flows from the southwest rift zone reached the ocean along the west coast of Hawai' $i$ within a matter of hours. In 1855-56 and 1880-81, lava from Mauna Loa's northeast rift zone did not reach the ocean but covered land now within the city limits of Hilo. Geologic mapping of Mauna Loa shows that, in the past 150 years, 14 percent $\left(714 \mathrm{~km}^{2}\right)$ of the volcano's surface was covered by new lava flows. As much as 35 percent to 40 percent $\left(1,800\right.$ to $\left.2,060 \mathrm{~km}^{2}\right)$ —an area equal to or greater than $\mathrm{O}^{`} \mathrm{ahu}$ or Maui-was covered in the past 1,000 years. 


\section{Risk Posed to Residents of the Island of Hawai' i}

According to the 2010 census, the Island of Hawaii is the fastest growing region in the State of Hawai' $i$, with more than 100,000 residents and a population that grew by 24 percent in the past decade. High levels of interest and affordable land lead to developmental pressures, which means that more and more construction will occur on the flanks of the island's volcanoes.

This rapid growth includes several multimillion-dollar developments built or proposed on the slopes of Mauna Loa in Waikoloa, Hilo, and Hawaiian Ocean View Estates- the last is the Nation's largest development in terms of area. Between 1984, the most recent eruption of Mauna Loa, and 2002, approximately \$2.3 billion were invested in new construction on the flanks of the volcano.

\section{Monitoring and Emergency Plan- ning Are Ongoing}

Volcanoes often show signs of unrestsuch as increased seismicity (earthquakes), deformation (inflation) of the volcano's flanks, and emission of volcanic gases-days to months in advance of an eruption. The USGS's Hawaiian Volcano Observatory (HVO) has recently upgraded its monitoring networks to improve its ability to detect early unrest. $\mathrm{Nu}-$ merous seismic, GPS, and tilt stations across the flanks of Mauna Loa keep a vigilant eye on the mountain 24 hours a day. When unrest is detected, scientists notify emergency-management officials and increase monitoring efforts.

\section{Volcano Hazards from Mauna Loa}

Lava-flow hazard maps prepared by the USGS for the Island of Hawai ' $i$ divide the island into nine hazard zones, with Zone 1 being the area of greatest hazard. The criteria used to establish these zones are (1) proximity to the summits and rift zones of the active volcanoes, (2) frequency of lava coverage during historical time (since about 1800), (3) area covered within the past 750 years, and (4) topography.

For Mauna Loa, Zone 1 includes the summit and rift zones and Zone 2 includes the regions downslope and adjacent to Zone 1. Zone 3 includes regions that appear less hazardous because of greater distance from the summit and rift zones. These three zones cover most of Mauna Loa, although portions of the east and southeast flanks are protected from lava flows by topography and consequently are in a lower hazard designation of Zone 6 .

Although the threat posed by eruptions from Mauna Loa's summit and rift zones is clear, the threat posed by vents outside these areas was not fully appreciated until recently. Such "radial vents" occur over a wide area

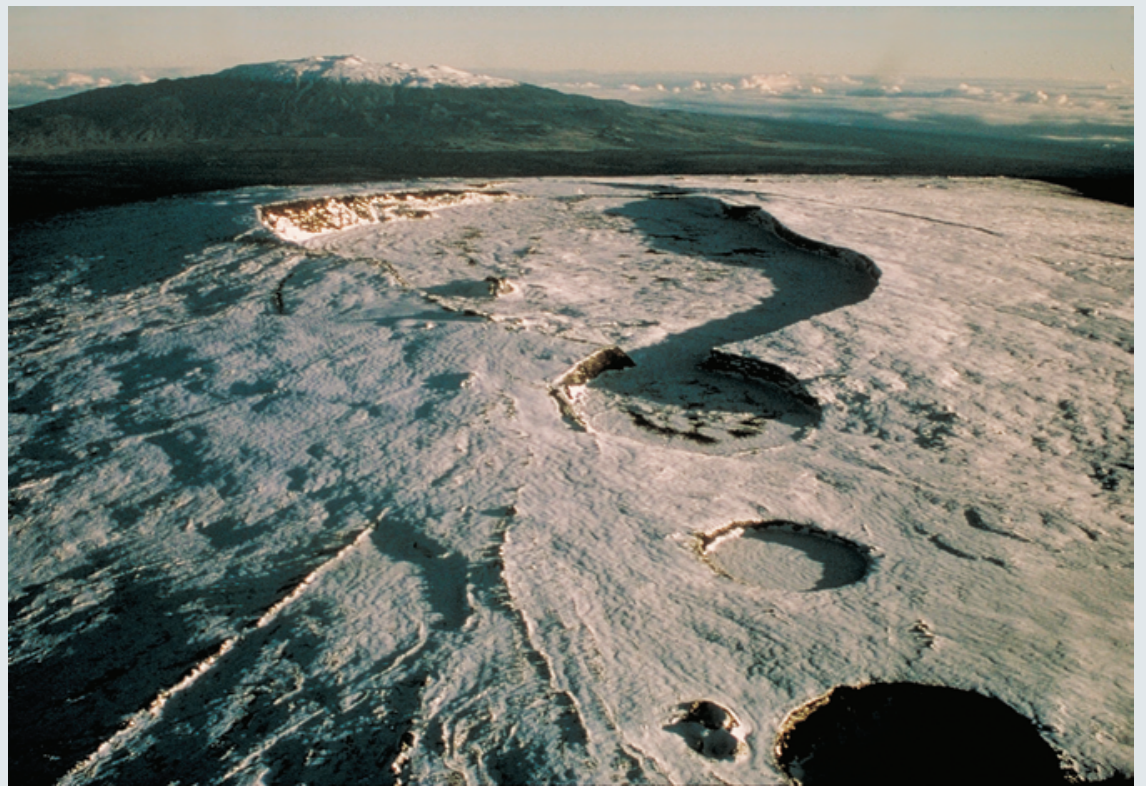

Aerial photograph looking north-northeast across the summit area of Mauna Loa (elevation 4,169 meters or 13,679 feet). At the summit is Moku'āweoweo Caldera, a volcanic depression 3 miles ( 5 kilometers) long. The pit craters in the foreground are part of the upper southwest rift zone. Mauna Kea Volcano rises on the skyline.

on Mauna Loa's north and west flanks, and new geologic mapping, additional age dating, and bathymetric surveys have resulted in the discovery of additional ones. Radial vents are located at all elevations from the summit of the volcano, at more than $4,000 \mathrm{~m}(>13,000 \mathrm{ft})$, to below sea level on the submarine flanks. Of the more than 45 known eruptions from radial vents, 3 have occurred in the past 150 years and 2 of those reached the sea.

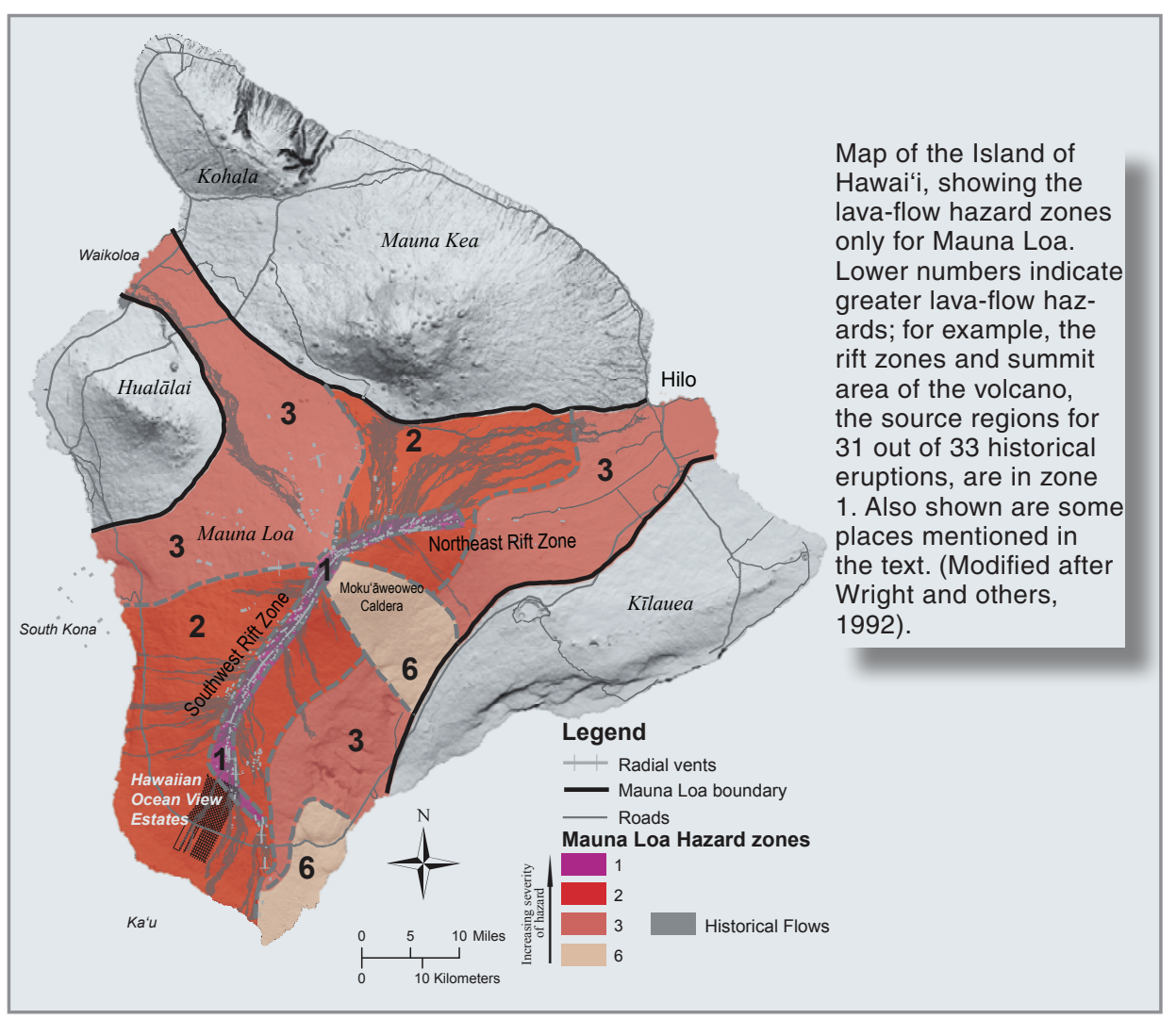


Characterizing the hazards posed by radial vents is a challenge. Radial vents are scattered over a broad area, unlike the narrow, well-defined rift zones of Mauna Loa, which more easily allow forecasting of future eruption locations. By using the same criteria that define lava-flow hazard zones on the current Lava Flow Hazards map with the new data on Mauna Loa's radial vents, Zone 2 should now extend down the northwest flank 20 $\mathrm{km}$ toward the coast, a distance comparable to the width of Zone 2 on the west side of the southwest rift zone.

If a Mauna Loa eruption occurs along the southwest rift zone, slopes steeper than 15 degrees, a history of high effusion rates, and the close proximity of developed areas put South Kona and $\mathrm{Ka}^{\prime} \mathrm{u}$ at significant risk. Precious little time may be available for response or evacuation efforts. On the other hand, the Hilo District is relatively far from the most active part of Mauna Loa's rift zones, and the slopes above that city are fairly gentle. Thus, while northeast rift zone eruptions can certainly threaten Hilo (parts of which are built on the 1881 flow), the lead time for response and evacuation is likely to be substantially longer (days to weeks) than for eruptions on the southwest rift zone (hours).

Other hazards posed by Mauna Loa include earthquakes and ground motion due to volcanic activity and to vertical and horizontal movements of the volcano's flank that can cause significant damage. As magma enters and inflates Mauna Loa, the volcano becomes unstable, setting the stage for the flank to slip and generate large earthquakes. Extremely destructive earthquakes have occurred beneath the Island of Hawai ' $i$ during times of inflation - notably the magnitude 8 earthquake of April 2, 1868, on Mauna Loa and, more recently, the magnitude 7.2 earthquake of November 29, 1975, on Kîlauea. Rapid flank adjustments that accompany large earthquakes can affect hundreds of square kilometers and can generate tsunamis that pose great risks to coastal communities. Although earthquakes cannot be predicted, people can be prepared for them through sound construction of buildings and protection of valuables.

Plumes of volcanic gases associated with eruptions, otherwise known as "vog" or volcanic smog, are also a concern - a nuisance and potential health hazard to people downwind and a threat to agricultural crops, livestock, and native biota. During the 1984 eruption of Mauna Loa, vog blanketed much of the State of Hawaii.

Explosive eruptions at the summit of Mauna Loa are a new discovery, and ash deposits on the southeast flank of the volcano are evidence of a potentially explosive past. Tiny chilled lava particles from high lava fountains, as well as ash from more powerful explosive eruptions, can drift into the airline approach corridors for Hilo and Kona airports.

Eruptions are an inevitable part of Mauna Loa's future, and risk will continue to grow as

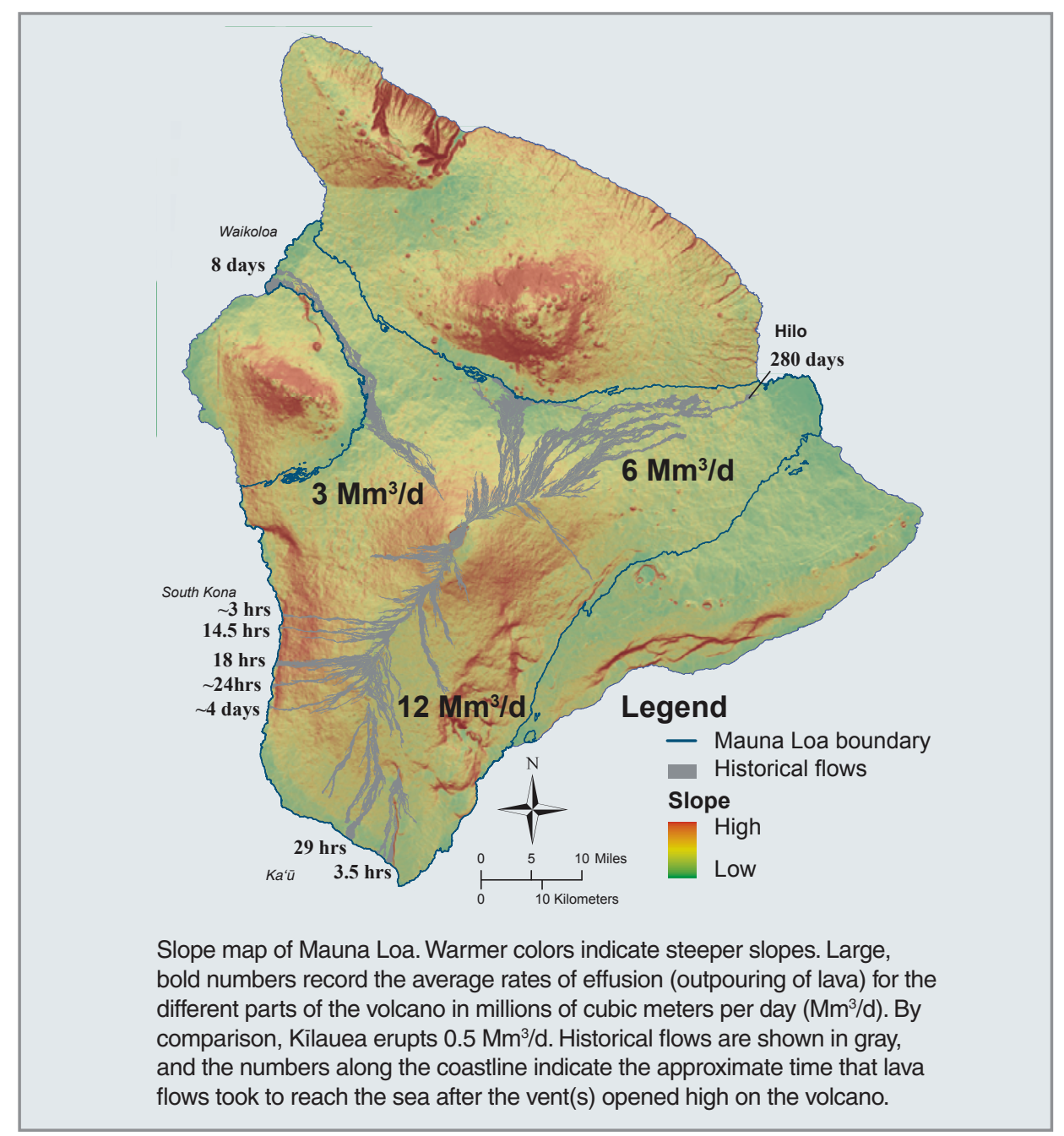

population and development increase. But the hazards associated with this majestic volcano can be anticipated, and the risks diminished substantially, by vigilant monitoring of the volcano's behavior, careful documenting of its past behavior as a guide to the future, and educating residents, visitors, and local leaders.

\section{What You Can Do if You Live On or Near Mauna Loa}

- Learn about the volcano hazards that could affect your community.

- Develop an emergency plan with your family so that you are prepared for natural hazards and emergencies.

- Help your community be prepared. A few moments spent in preparation now could keep you, your family, and your community safe when Mauna Loa next erupts.

The primary mission of HVO is to issue timely and accurate warnings of hazardous volcanic activity, and one of its goals is to assess volcano hazards and promote public awareness through education. HVO is part of the USGS Volcano Hazard Program's ongoing efforts to help protect people's lives and property in all of the volcanic regions of the United States, including Hawai 'i, California, the Pacific Northwest, Wyoming, Alaska, and the Commonwealth of the Northern Marianas.

$$
\begin{gathered}
\text { Frank A. Trusdell } \\
\text { Edited by } \\
\text { Peter H. Stauffer } \\
\text { Graphic design by } \\
\text { Stephen L. Scott }
\end{gathered}
$$

For more information contact:
U.S. Geological Survey
Hawaiian Volcano Observatory
P.O. Box 51
Hawai'i National park, HI 96718
http://hvo.wr.usgs.gov/
or
USGS Volcano Hazards Program
http://volcanoes.usgs.gov/
(N)
(NVEWS)
See also The National Volcano Early Warning System
(USGS Fact Sheet 2006-3142)
This Fact Sheet and any updates to it are available online at
http://pubs.usgs.gov/fs/2012/3104/

